\title{
Limnological Comparisons of Threats to Aquatic Life Owing to Thermal Stratification in two Morphometrically Different Urban Shallow Lakes
}

\author{
*Nihar R. Samal ${ }^{1}$ Pankaj K. Roy ${ }^{2}$ and Malabika B. Roy ${ }^{3}$ and Asis Mazumdar ${ }^{2}$ \\ ${ }^{1}$ Institute for Sustainable Cities, City University of New York, 695 Park Ave. New York, NY 10065, USA \\ ${ }^{2}$ School of Water Resources Engineering, Jadavpur University, Kolkata -700032, WestBengal, India \\ ${ }^{3}$ Gandhi Centenary B.T. College, Habra, North $24^{\text {th }}$ Parganas, West Bengal, INDIA \\ Author for correspondence: samalnr@gmail.com
}

\begin{abstract}
A minimum value in the Dissolved Oxygen distribution of two shallow lakes namely, Rabindra Sarobar in south Kolkata and Subhas Sarobar in East Kolkata in the Gangetic Delta plain, has been observed to develop in the Hypolimnion during the stratified period. This minimum is usually explained by the accumulation of organic matter from the overlying layer of water. The introduction of organic matter from allochthonous and autochthonous sources is also a likely contributor to the accelerated oxygen depletion within Hypolimnion. The thermal stratification, in general, which occurs in these tropical lakes, is of direct relevance in maintaining the water quality standards, particularly for higher aquatic life. The present article attempts to investigate the possible depletion of hypolimnetic oxygen depletion as a result of the impact of thermal stratification. These investigations will be the basic guidelines for the fishermen and their livelihoods potentially depend upon the different varieties of fishing on daily basis. The massive summer fish kills in these lakes is a major devastating happenings that is reported by the fishermen and also it is well evident from our experimental observations. The comparison of the biodiversity of these two lakes is attempted in the present investigation.
\end{abstract}

Key Words: Thermal stratification, Dissolved Oxygen, Tropical Shallow Lake, Hypolimnion, biodiversity.

\section{Introduction}

Understanding of the transport mechanisms in tropical lakes are now-a-days an important and essential aspect in the study of water quality and the sustenance of aquatic life (Samal et al. 2009; Samal et al. 2010; Joehnk et al. 2001; Samal and Mazumdar 2005b). The seasonal development of the thermal stratification in lakes/waterbodies is an indicative of vertical mixing processes which are central to the understanding of the transport of nutrients, dissolved oxygen and other parameters characterizing water 
quality (Peeters et al. 2002; Samal, 2004). Water quality deterioration (Biswasroy et al. 2012c) and its impact on sustenance of aquatic life in the freshwater lakes develops a basis for the quantification of vertical mixing processes that govern not only the thermal structure but also the nutrient exchanges, and more generally the distribution of dissolved oxygen between the different parts of the lake (Maclntyre et al. 2010; Goudsmit et al. 2002; Peeters et al. 2007; Samal et al. 2012). This becomes important if the lake is stratified. In such a case the euphotic zone where the phytoplankton grows is essentially a zone of oxygen and organic matter production and of nutrients consumption (Livingstone and Imboden, 1996). On the other hand, organic matter is decomposed and oxygen is consumed, whereas nutrients are redissolved in deeper layers (Samal et al. 2004b). Assessing the exchanges between these two areas is important because they influence the tropic organization of the ecosystem. In depth physical description of the hydrodynamics, is therefore, a necessary prerequisite in the understanding of freshwater ecosystems as physical, chemical and biological processes interact in several ways and at various timeand spatial-scales (Bonnet, M.P. et al. 2000). The open discharge of various kinds of wastes to urban lakes is the major source of large scale contamination (Samal et al. 2011), which makes these urban lakes unfit for the major use for urban people and the ecosystem as well. Further, the tropical storm drives external sources of contaminants through surface runoff and sudden drop in air temperature and water temperature in lakes weakens the water column stability (Klug et al. 2012) and mixes the whole water column into an isothermal condition. However, the development of the dissolved oxygen minimum in the hypolimnion zone in both the Rabindra Sarobar and Subhas Sarobar is usually attributed to the settling of organic matter from the overlaying water followed by accelerated dissolved oxygen consumption within this restricted layer. The duration of stratification and other dependent metrics are needed to be estimated using a model study (Samal et al. 2009; 2012), which substantiates the time window for the oxygen depletion in the water column. Though various one dimensional (vertical) deterministic water quality models are developed, the most simplified hydrothermal models are the recent concern of many researchers to verify, test and compare those models for better prediction of hydrothermal indices under the hydrological induced climate change conditions (Yao et al 2014). The present article attempts to investigate the possible depletion of hypolimnetic oxygen depletion as a result of the impact of thermal stratification. These investigations will be the basic guidelines for the fishermen and their livelihoods potentially depend upon the different varieties of fishing on daily basis. The massive summer fish kills in these lakes is a major devastating happenings that is reported by the fishermen and also it is well evident from our experimental observations. Keeping in view the socieoeconomic status of these large numbers of fishermen and their dependency, these study necessities the 
investigations of the hydrodynamics of the lakes (Biswasroy et al. 2010; 2011; 2012a; 2012b). The investigations of the impact of thermal stratification in these tropical lakes will give a broad idea about the sustenance of higher aquatic life forms (i.e. fish), which is very much essential for meeting the livelihoods of these large number of fishermen. The comparison of the biodiversity of these two lakes is also attempted in the present paper.

\section{Material and Methods}

Site description: The study has been carried in the Rabindra Sarobar (Basin-K) in South Kolkata and Subhas Sarobar in East Kolkata (Figure 1) during the peak summer time (May 2003). The limnological details of these lakes are described in Table 1.

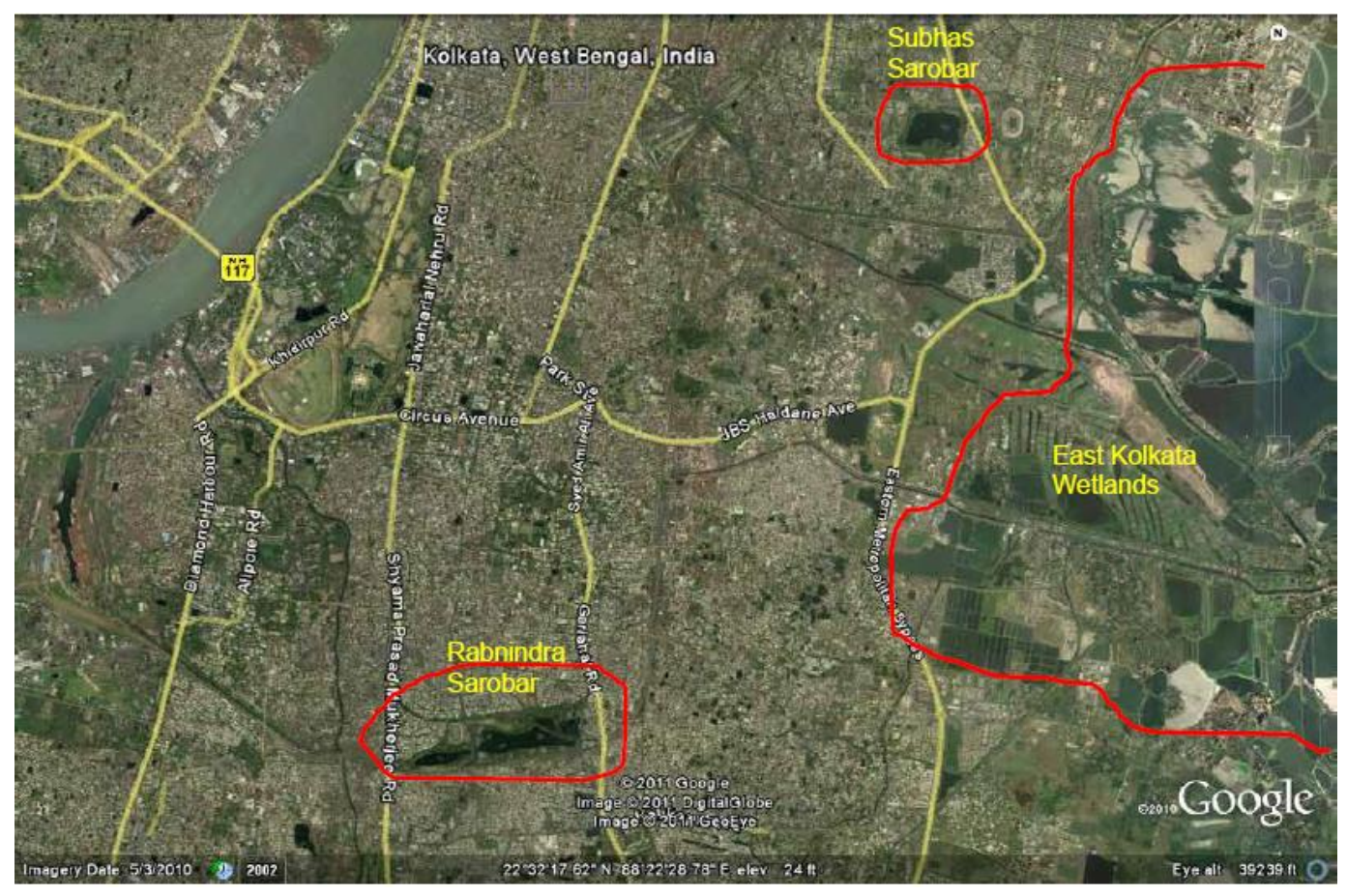

Figure 1. Map of urban tropical shallow lake in eastern India: Rabindra Sarobar and Subhas Sarobar 
Table 1. Main limnological parameters of Lakes of Central Calcutta Metro city

\begin{tabular}{|c|c|c|c|c|}
\hline & Limnological characteristics & Unit & $\begin{array}{l}\text { Rabindra Sarobar } \\
\text { (Basin-K) }\end{array}$ & Subhas Sarobar \\
\hline 1 & Latitude & & $22^{0} 34^{\prime} \mathrm{N}$ & $22^{0} 34^{\prime}-22^{0} 34^{\prime} 30^{\prime \prime} \mathrm{N}$ \\
\hline 2 & Longitude & & $88^{\circ} 23^{\prime} \mathrm{E}$ & $88^{0} 24^{\prime}-88^{\circ} 24^{\prime} 30^{\prime \prime} \mathrm{E}$ \\
\hline 3 & Lake altitude (a.m.s.l) & (m) & 6.0 & 6.0 \\
\hline 4 & Lake complex area (LCA) & $\left(\times 10^{4} \mathrm{~m}^{2}\right)$ & 78.07 & 39.6 \\
\hline 5 & Lake water area $(\mathrm{A})$ & $\left(\times 10^{4} \mathrm{~m}^{2}\right)$ & 17.1 & 16.0 \\
\hline 6 & Lake water area/Lake complex area & $\left(\times 10^{4} \mathrm{~m}^{2}\right)$ & 0.22 & 0.40 \\
\hline 7 & Total Lake area $\left(A_{t}\right)$ & $\left(\times 10^{4} \mathrm{~m}^{2}\right)$ & 17.68 & 16.29 \\
\hline 8 & Lake water volume (V) & $\left(\times 10^{3} \mathrm{~m}^{3}\right)$ & 532.2 & 634.2 \\
\hline 9 & Maximum length $\left(L_{\max }\right)$ & (m) & 1085 & 617 \\
\hline 10 & Maximum effective length $\left(L_{e}\right)$ & (m) & 379.2 & 366 \\
\hline 11 & Mean length (L) & (m) & 1082 & 516 \\
\hline 12 & Effective length ( $\left.\mathrm{L}_{s}\right)$ & (m) & 396 & 354 \\
\hline 13 & Fetch area $\left(F_{\text {area }}=\right.$ Area $\left.^{1 / 2}\right)$ & $\left(\times 10^{2} \mathrm{~m}^{2}\right)$ & 4.1 & 4.0 \\
\hline 14 & Effective fetch $\left(F_{\text {eff }}\right)$ & (m) & 261.6 & 259.5 \\
\hline 15 & Maximum width $\left(\mathrm{B}_{\max }\right)$ & (m) & 269 & 352 \\
\hline 16 & Maximum effective width $\left(B_{e}\right)$ & (m) & 144 & 153 \\
\hline 17 & Mean width (B) & (m) & 184 & 326 \\
\hline 18 & Maximum depth $\left(Z_{\max }\right)$ & (m) & 5.7 & 10.36 \\
\hline 19 & Mean depth $\left(Z_{\text {mean }}\right)$ & $(\mathrm{m})$ & 3.5 & 4.8 \\
\hline 20 & Relative depth $\left(D_{r}\right)(\%)$ & & 1.2 & 2.3 \\
\hline 21 & Shoreline length $\left(I_{0}\right)$ & $(\mathrm{m})$ & 2642.4 & 1855.2 \\
\hline 22 & Total shoreline length $\left(I_{t}\right)$ & (m) & 3280.8 & 2173.18 \\
\hline 23 & Shoreline development $\left(D_{L}\right)$ & & 1.7 & 1.3 \\
\hline 24 & Volume development $\left(V_{d}\right)$ & & 1.8 & 1.4 \\
\hline 25 & Insulosity $\left(I_{n}\right)(\%)$ & & 3.3 & 1.8 \\
\hline 26 & Maximum Secchi-Depth & (m) & 1.50 & 1.70 \\
\hline
\end{tabular}


(a)

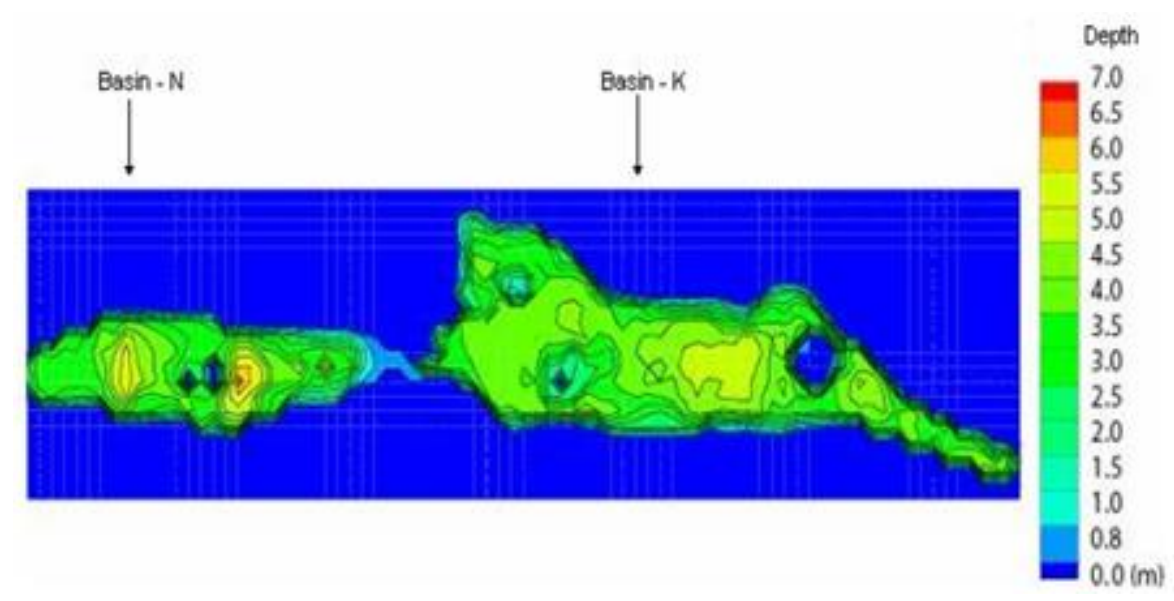

(b)

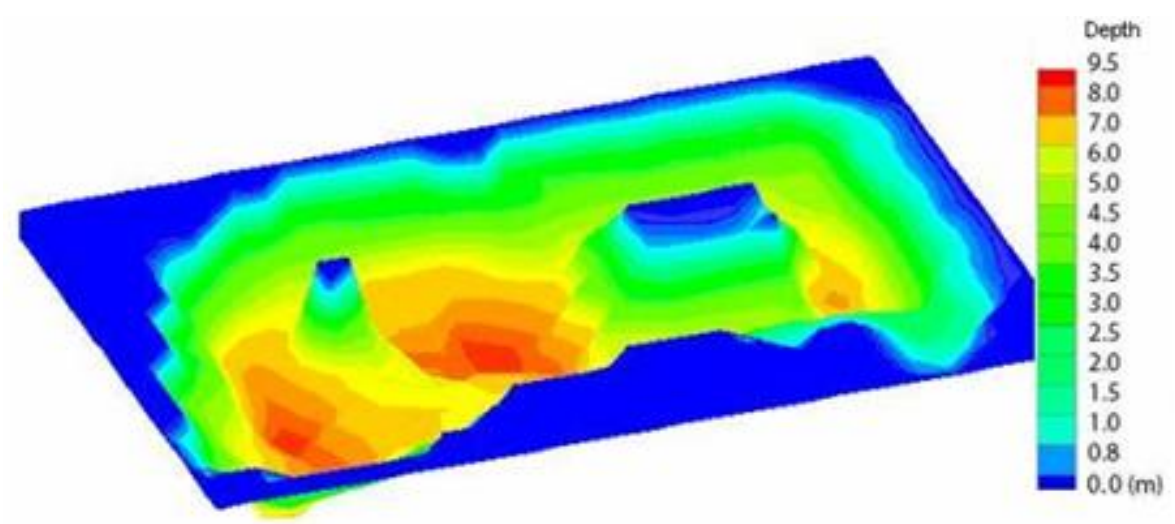

Figure 2. Bathymetric map of Rabindra Sarobar (a) and Subas Sarobar (b)

The Rabindra Sarobar (erstwhile the Dhakuria Lake) spread over an area of 78.07 ha having a water area of 29.54 ha. The lake complex comprises of four waterbodies (Lake-K, L, M, N), four boating clubs, a sports stadium complex, an open-air auditorium complex, parks, motorable roads, paved footpaths, open space with greeneries etc. The large lake, that is Lake-K with two small islands within having water area (about $17.1 \mathrm{ha}$ ) is considered for the present study. The hypsographic and volumetric curve for basin $-\mathrm{K}$ of Rabindra Sarobar are shown in Figures 2 and 3. 

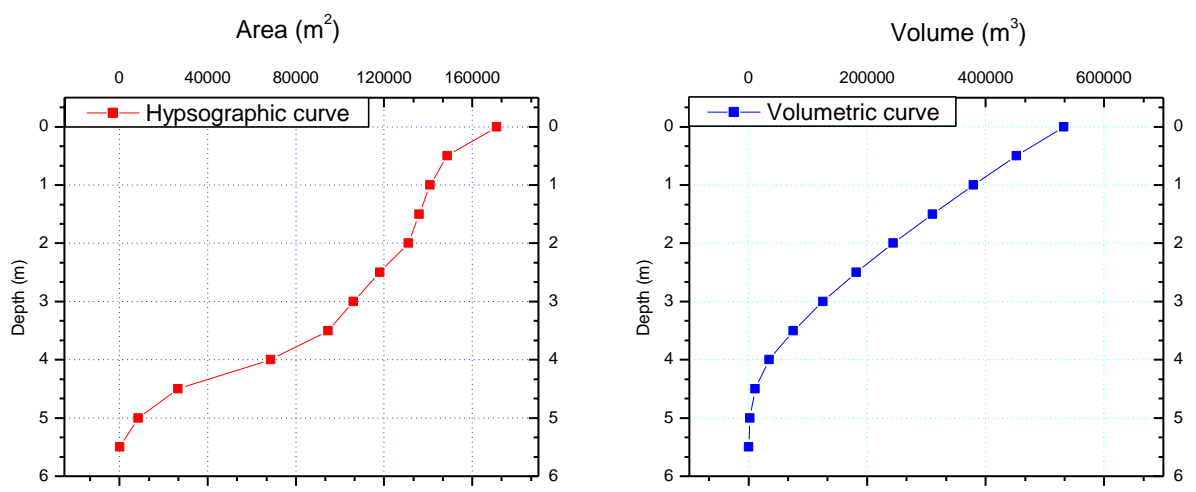

Figure 3. Hypsographic and volumetric curve for basin -K of Rabindra Sarobar

The Subhas Sarobar covers an area of 39.6 ha, of which the water area is about 6.04 ha. Two islands, one small and the other big, constitute an excellent habitat for diverse species of life. The mean length and width of the Lake are $0.584 \mathrm{~km}$ and $0.326 \mathrm{~km}$ respectively while the maximum depth and the mean depth of the lake are $10.36 \mathrm{~m}$ and $9.6 \mathrm{~m}$ respectively. The hypsographic and Volumetric curve for Subhas Sarobar is shown in Figures 2 and 4.
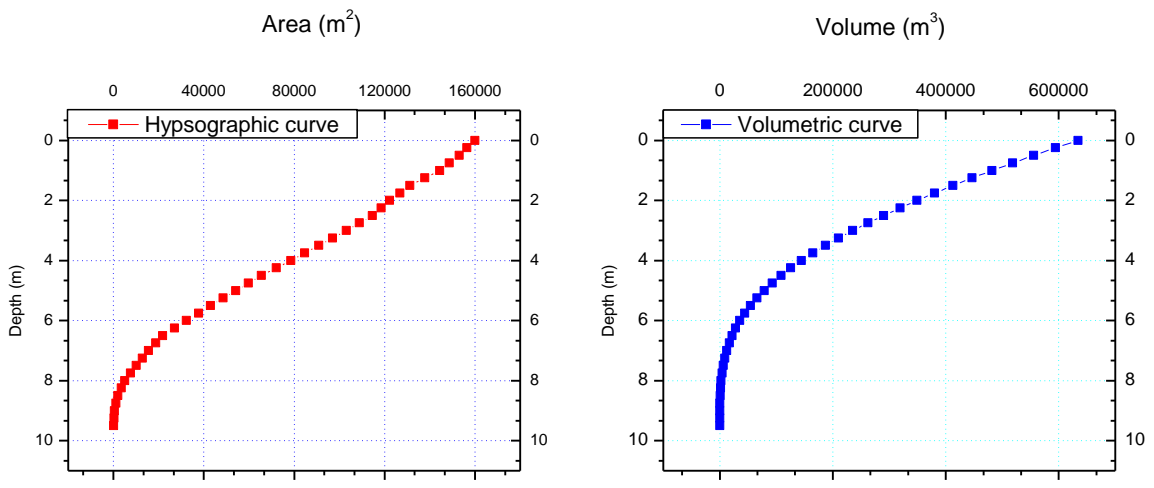

Figure 4. Hypsographic and Volumetric curve for Subhas Sarobar

The major basins of lake, Rabindra Sarobar (basin-K) and the lake, Subhas Sarobar are morphometrically different and the hypsographic curve, which is a graphical representation of the relationship of the surface area (i.e. water surface area) of a lake to its depth and the volumetric curve, 
which represents the relationship of water volume of the lake to depth, are illustrated in Figure 2 and Figure 4.

The waterbody is given on rent to the Department of Fisheries of Government of West Bengal. A part of the waterbody is used as a public swimming pool. The open space in both the lakes is an oasis in the space-starved conjested city. The lake complex is used for sports including watersports, recreation and cultural activities. Presently, water of the Sarobar is intensively used for bathing, washing, cleaning and community purposes by a large number of people who live in the slum area adjacent to the Sarobar. Fishing in these lakes is the major livelihood support for a large number of fishermen. Everyday fishermen used to catch fishes and sale them in the market. The detailed quantifications of the fishes and the variety of fishes are not available and still under investigations. Both the lake is under the administrative control of Kolkata Improvement Trust.

Sampling procedure: in any water quality study, sampling is crucial with regards to mode of collection (i.e. time, location, depth of water, etc.). The observation sites are selected considering the maximum water depth along the mid-reach (Station-I, II \& III) and considering the less human intervention of water of the Lake, to study the thermal stratification. The water depths of these stations are more or less variable. The water temperature and Dissolved Oxygen (DO) have, however, been measured using a WTW DO meter along the depth at an interval of $0.5 \mathrm{~m}$ below the water surface. The concentration of Biochemical Oxygen Demand (BOD) has been estimated at the same depth in the water analysis laboratory of School of Water Resources Engineering following the standard method of APHA (1989). The water samples have been collected from these specific sites in the Rabindra Sarobar on 22.05.2003 and in the Subhas Sarobar on 28.05 .2003 by a water sampler having capacity one litre separately for each site, which is locally made and specially designed by the School Water Resources Engineering, Jadavpur University. The samples after collection have been stored in the deep freeze to avoid any microbial decomposition. The biological parameters such as, phytoplankton, rate of primary production, and diversity and abundance of zooplankton in these lakes are also determined using the biological methods.

\section{Results and discussion}

Morphometric variation between these two urban shallow lakes: the hypsographic curve and the volumetric curve of this two basins fits well to the polynomial form and the variation of volume along the depth is same, which is characterised by the correlation between the depth and volume (99\%). The 
area-volume relation in the basin $-\mathrm{K}$ shows a better fit to the polynomial form, while in the basin $-\mathrm{N}$, the area-volume is favoured by a power function, and the correlation factor in both the basin is same (97\%) for the different area-volume in the lake. The volume remains almost constant below the depth of $4.5 \mathrm{~m}$ from the water surface. The hypsographic and volumetric curve for Subhas Sarobar is shown in Figure 3. Here the hypsographic and the volumetric curve also fit well to the polynomial form and the correlation between area-depth and volume-depth in the lake is $99 \%$. The area-volume relation follows the power function and its correlation is also $99 \%$. This waterbody has been leased to the Department of Fisheries of Government of West Bengal for commercial purposes e.g. angling.

These better correlations in area-depth, volume-depth and area-volume in these three morphometrically different lakes may be explained by saying that volume also holds information about the lake surface, as it is calculated by multiplying the lake surface area by mean depth, and because wind effects are mainly controlled by lake surface dimensions, which induces vertical mixing along the vertical depth direction and volume integrates all influences on thermal stratification and heat content, coming from both inside (morphometry) and the outside.

Vertical distribution of physico-chemical parameters: depth-wise studies of physico-chemical parameters in the selected observation sites along the mid-reach of the lake revealed a distinct change in value giving rise to the important hydrodynamical events occurring in shallow/deeper lakes in this tropical climate. The thermal stratification is the result of energy exchanges between water and the surrounding environment, particularly the atmosphere. The most important energy source is solar radiation, which is absorbed directly by the water mass, except for rather a small quantity that is reflected by the liquid surface (Barbanti et al. 1981). The ways by which heat is transported from the lake surface into the water mass are controlled by both external (Particularly, wind, the main driving variable behind any movements in Lakes) and by internal factors such as Lake shape, size and particularly the depth (Samal et al. 2008). Depth is one of the most important characteristics of a Lake, because on it depends the proportion of the lake's volume, which receives solar radiation. The heat provided by this determines any thermal stratification and stability of the Lake. 


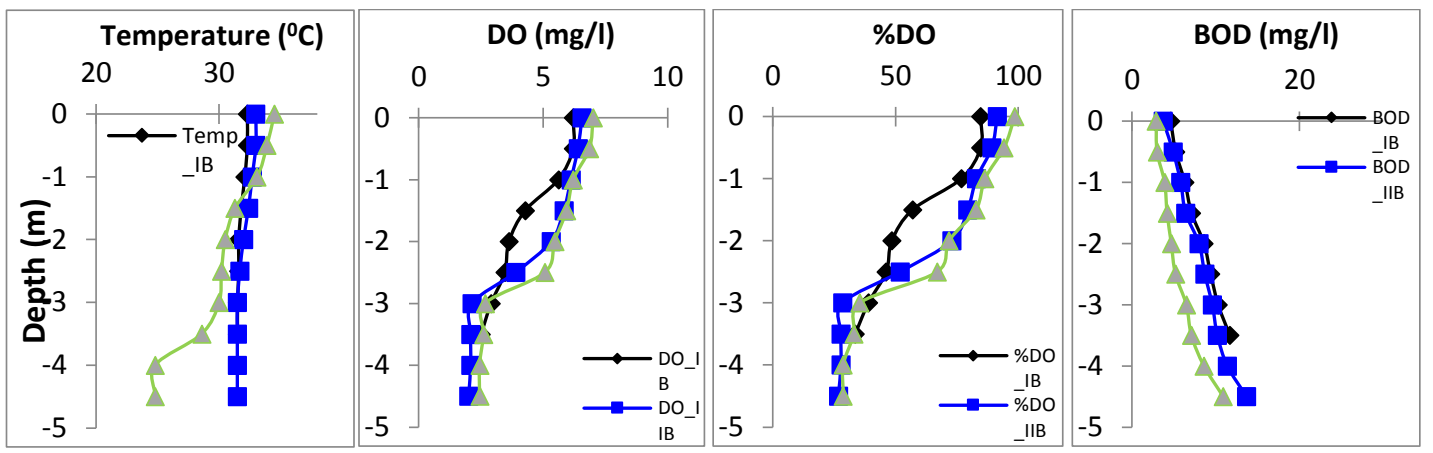

Figure 5. Vertical distribution of Temperature, Dissolved Oxygen (DO), \% DO and Biochemical Oxygen Demand (BOD) in Rabindra Sarobar Lake

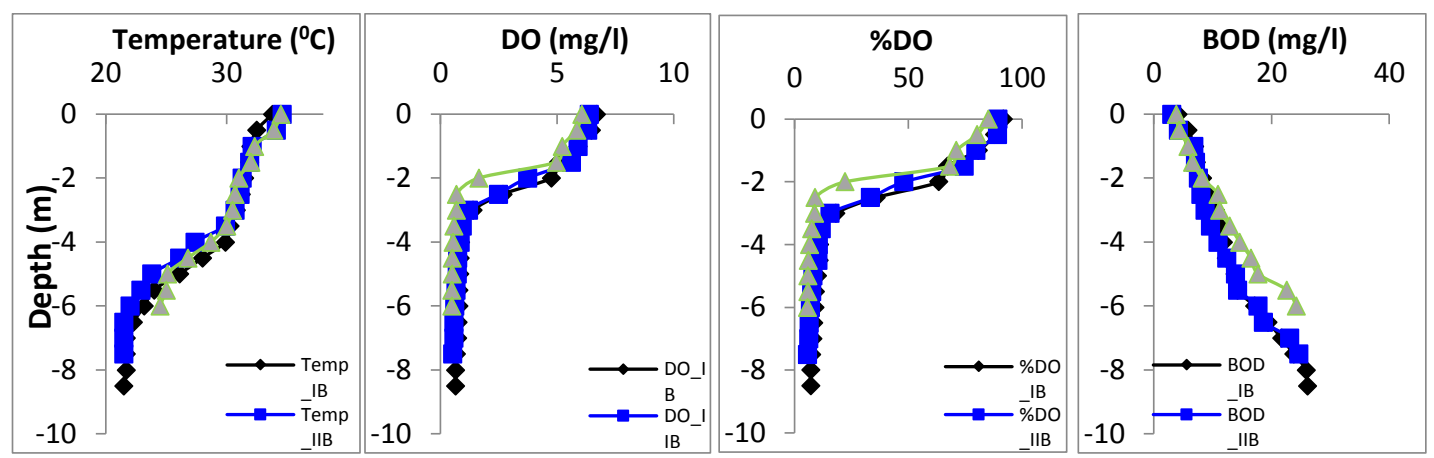

Figure 6. Vertical distribution of Temperature, Dissolved Oxygen (DO), \% DO and Biochemical Oxygen Demand (BOD) in Subhas Sarobar Lake

In the present investigation, the variation of the temperature, dissolved oxygen (DO), \% DO and the Biochemical Oxygen Demand (BOD) along the depth at stations IB, IIB, IIIB for Rabindra Sarobar and Subhas Sarobar is given in Figures 5 and 6 . These data show the development of the thermal stratification and dissolved oxygen stratification in both the lakes. The pattern of stratification is observed to be clear in case of the deep lake i.e. Subhas Sarobar in comparision to the shallow lake i.e. Raibindra Sarobar. The maximum and minimum depth is found to be $8.5 \mathrm{~m}$ and $6.0 \mathrm{~m}$ in station IB and IIIB for Subhas Sarobar and $4.5 \mathrm{~m}$ and $3.5 \mathrm{~m}$ in stations IIB, IIIB and IB for Rabindra Sarobar. The surface water temperature and bottom water temperature is found to be maximum $\left(34.5^{\circ} \mathrm{C}\right)$ and minimum $\left(24.8^{\circ} \mathrm{C}\right)$ at station-IIIB for Rabindra Sarobar while surface water temperature and bottom water temperature is found to be maximum $\left(34.6^{\circ} \mathrm{C}\right)$ at station-IIB and minimum $\left(21.5^{\circ} \mathrm{C}\right)$ at stations-IB \& IIB. The average air temperature and wind speed above the lake water surface is observed to be $36.6{ }^{\circ} \mathrm{C}$ and $1.88 \mathrm{~m} / \mathrm{s}$ for the Subhas Sarobar and $35.9{ }^{\circ} \mathrm{C}$ and $1.92 \mathrm{~m} / \mathrm{s}$ for the Rabindra Sarobar. But the variation 
trend of temperature in the hypolimnion zone for both the lakes remain same at stations-IB \& IIB. Again the temperature exhibits a good negative correlation with depth at all the stations for both the lakes, which is detailed in Table 1-6.

The dissolved oxygen concentration remain constant in the hypolimnion zone in both the lakes and however, follows the same trend of variation with temperature and opposite trend of variation with Biochemical Oxygen Demand (BOD) in both the lakes. The dissolved oxygen content in the surface water and bottom water is found to be maximum $(7.01 \mathrm{mg} / \mathrm{l})$ and minimum $(2.00 \mathrm{mg} / \mathrm{l})$ at station-IIIB \& IIB for Rabindra Sarobar while dissolved oxygen content in the surface water and bottom water is found to be maximum $(6.67 \mathrm{mg} / \mathrm{I})$ at station-IB and minimum $(0.48 \mathrm{mg} / \mathrm{l})$ at station-IIIB. Low value of dissolved oxygen near the sediment-water interface develops the hypoxic condition ( $\mathrm{DO}<5 \mathrm{mg} / \mathrm{l}$ ) and it gradually extended upward throughout the summer. As a result of thermal stratification the bottom layer is cut-off from atmospheric oxygen and oxygen-producing plants. In the present study, the water temperature possesses a good positive correlation with dissolved oxygen at all the stations of Rabindra Sarobar and Subhas Sarobar, detailed in Table 2-7.

Table 2. Correlation coefficient among Depth, Temperature, DO, \% DO and BOD at the Mid-reach of Station-I of Rabindra Sarobar

\begin{tabular}{llllll}
\hline & Depth & Temperature & DO & \% DO & BOD \\
Depth & 1.000 & & & & \\
Temperature & -0.952 & 1.000 & & & \\
DO & -0.977 & 0.990 & 1.000 & & \\
\% DO & -0.973 & 0.991 & 1.000 & 1.000 & \\
BOD & 0.997 & -0.948 & -0.976 & -0.972 & 1.000 \\
\hline
\end{tabular}

Table 3. Correlation coefficient among Depth, Temperature, DO, \% DO and BOD at the Mid-reach of Station-II of Rabindra Sarobar

\begin{tabular}{llllll}
\hline & Depth & Temperature & DO & $\%$ DO & BOD \\
Depth & 1.000 & & & & \\
Temperature & -0.947 & 1.000 & & & \\
DO & -0.952 & 0.942 & 1.000 & & \\
$\%$ DO & -0.955 & 0.948 & 1.000 & 1.000 & \\
BOD & 0.991 & -0.920 & -0.924 & -0.927 & 1.000 \\
\hline
\end{tabular}


Table 4. Correlation coefficient among Depth, Temperature, DO, \% DO and BOD at the Mid-reach of Station-III of Rabindra Sarobar

\begin{tabular}{llllll}
\hline & Depth & Temperature & DO & \% DO & BOD \\
Depth & 1.000 & & & & \\
Temperature & -0.965 & 1.000 & & & \\
DO & -0.957 & 0.890 & 1.000 & & \\
\% DO & -0.968 & 0.907 & 0.998 & 1.000 & \\
BOD & 0.957 & -0.960 & -0.911 & -0.921 & 1.000 \\
\hline
\end{tabular}

Table 5. Correlation coefficient among Depth, Temperature, DO, \% DO and BOD at the Mid-reach of Station-I of Subhas Sarobar

\begin{tabular}{llllll}
\hline & Depth & Temperature & DO & $\%$ DO & BOD \\
Depth & 1.000 & & & & \\
Temperature & -0.969 & 1.000 & & & \\
DO & -0.856 & 0.764 & 1.000 & & \\
$\%$ DO & -0.862 & 0.771 & 1.000 & 1.000 & \\
BOD & 0.977 & -0.952 & -0.754 & -0.760 & 1.000 \\
\hline
\end{tabular}

Table 6. Correlation coefficient among Depth, Temperature, DO, \% DO and BOD at the Mid-reach of Station-II of Subhas Sarobar

\begin{tabular}{llllll}
\hline & Depth & Temperature & DO & $\%$ DO & BOD \\
Depth & 1.000 & & & & \\
Temperature & -0.979 & 1.000 & & & \\
DO & -0.884 & 0.828 & 1.000 & & \\
$\%$ DO & -0.886 & 0.832 & 0.999 & 1.000 & \\
BOD & 0.967 & -0.944 & -0.757 & -0.761 & 1.000 \\
\hline
\end{tabular}


Table 7. Correlation coefficient among Depth, Temperature, DO, \% DO and BOD at the Mid-reach of Station-III of Subhas Sarobar

\begin{tabular}{llllll}
\hline & Depth & Temperature & DO & $\%$ DO & BOD \\
Depth & 1.000 & & & & \\
Temperature & -0.981 & 1.000 & & & \\
DO & -0.859 & 0.792 & 1.000 & & \\
$\%$ DO & -0.862 & 0.795 & 1.000 & 1.000 & \\
BOD & 0.984 & -0.974 & -0.798 & -0.801 & 1.000 \\
\hline
\end{tabular}

The rate of oxygen depletion in the hypolimnion zone is extremely high in case of Subhas Sarobar as compared to Rabindra Sarobar which is consistent with the high value of BOD, as observed to be maximum (13.7 mg/l) and minimum (10.9 mg/l) at station-IIB \& IIIB for Rabindra Sarobar and maximum $(26.1 \mathrm{mg} / \mathrm{I})$ and minimum $(24.2 \mathrm{mg} / \mathrm{l})$ at station-IB \& IIIB for Subhas Sarobar. Again the DO concentration exhibits a good negative correlation with BOD value at all the stations as detailed in Table 1-6. The hypolimentic loss of dissolved oxygen is resulted primarily due to biological oxidation of organic matter reaching from the upper zone (epilimnion) of the lake thus enriching the hypolimnion with high amount of nutrients (Mazumdar, et al. 2007). The rate of oxidation probably increased in the vertical direction due to gradual decrease in the water volume and more pronounced at the sediment-water interface, a zone of higher bacterial decomposition with production of reducing components like $\mathrm{CO}_{2}, \mathrm{H}_{2} \mathrm{~S}$ etc. that lowered the $\mathrm{pH}$ of the medium, which is an indication of organic pollution (Wetzel, 1983).

The percentage of oxygen saturation (\% DO) at the surface is found to be maximum $(98.6 \%)$ at station-IIIB and minimum (84.7 \%) at station-IB in the Rabindra Sarobar while for Subhas Sarobar it is maximum (91.8 \%) at station-IB and minimum (85.2\%) at station-IIIB. Thus both the waterbody remained under-saturated with dissolved oxygen during our observation period indicating that the oxygen will diffuse into water in proportion to the oxygen deficit. Diffusion oxygen losses and gain can also be quite substantial, especially at windy sites when DO values are substantially different from $100 \%$ saturation. The spatial and temporal variation in the hypolimnion thickness indicates a warning for the aquatic species to look for oxygenated rich environment. As observed from the temperature and oxygen profile (Figure 3-8), the rate of oxygen consumption is rapid in the thermocline zone due to high temperature gradient and contribute to the development of minimum DO and is continued through out the summer and fall and persisted until thickening of the mixed layer destroyed it in early winter. Low 
value of DO can not enhance other chemical oxidation processes in the band of hypolimnion, resulting in increasing the toxicity of the water and the water quality becomes unfit for the sustenance of the aquatic life in the waterbody. Thus the biomechanisms scale maintaining the foodchain (Phytoplankton $\rightarrow$ Zooplankton $\rightarrow$ Small fish $\rightarrow$ Large fish) is hindered, whereby the whole aquatic ecosystem is under threat and the system is an almost endless chain or circle fueled by solar energy trapped in photosynthesis. The assimilation efficiency of the self-sustaining ecosystem is reduced and is highly seasonally variable (Samal et al. 2004a).

In fish culture, the tolerable limit of DO has been prescribed as $40 \%$ saturation level or $3.0 \mathrm{mg} / \mathrm{I}$ whichever is the higher in the medium (Samal et al. 2004; Samal et al. 2010). The DO value is found to drop below $1.0 \mathrm{mg} / \mathrm{I}$ at station-IB, IIB from depth of $3.5 \mathrm{~m}$ to the bottom and at station-IIIB from depth of $2.5 \mathrm{~m}$ to the bottom in the Subhas Sarobar, which accounts for a sudden fish die off. The depletion of dissolved oxygen in the hypolimnion and the variability in water column temperature may be highly dependent (Samal et al. 2004a) and the variability over time series is an indicator of climate change both in tropical and temperate weather conditions (Pierson et al. 2013; Samal et al. 2013).

Biological situation in Rabindra Sarobar and Subhas Sarobar: in Rabindra Sarobar, water temperature varied between 25.9 and $33.8^{\circ} \mathrm{C}$, which was highest during premonsoon and lowest during postmonsoon. Conductivity a major pollution indicator in inland water bodies, is fluctuated between 405.35 to $719.92 \mathrm{mmhos} / \mathrm{cm}$ (Das et al. 2006). Maximum turbidity value was recorded during monsoon and the water remained comparatively clear during the rest of the year. The $\mathrm{pH}$ fluctuated narrowly between different seasons. The contribution of chloride, phosphate, nitrate, nitrite and ammonia were lowest during postmonsoon and highest in premonsoon except for alkalinity value which was lowest during monsoon. The physicochemical characteristics of Subhas Sarobar is observed to be highly variable to that of Rabindra Sarobar except for noticeable variations in alkalinity, chloride content, conductivity and dissolved oxygen level. The major reason in these changes is due the lake depth (morphometric) effect and the number of daily users in the lake. Gross and Net Primary Productivity (GPP and NPP) values in Rabindra Sarobar varied between 1443.75-3662.5 and 412.5$2237.5 \mathrm{mgC} / \mathrm{m}^{3}$ per day, respectively (Samal and Mazumdar 2005). In Subash Sarobar, the values of GPP and NPP varied from 2171.25-3512 and 1375-2250.25 mgC/m³ per day. Maximum net:gross ratio was observed during monsoon and minimum during postmonsoon. Rabindra Sarobar harboured a total of 45 species of zooplankton with 19 Cladocera, 5 Copepoda, 20 Rotifera and 1 Ostracoda species. Alkaline and highly polymorphic cosmopolitan species dominated the faunal composition. Zooplankton species richness in Subhas Sarobar was comparatively higher than Rabindra Sarobar from where 48 
species were recorded. This was due to the higher number of Cladocera and Rotifera. Zooplankton density varied between 619-1144 units/litre in Rabindra Sarovar, and between 608-1238 units/litre in Subhas Sarobar with peak during monsoon (Samal and Mazumdar 2005). Seasonal fluctuation pattern was almost similar in both lakes. The zooplankton community as a whole was numerically dominated by Copepods followed by Cladocera. Rotifers, on the other hand, contributed only $14-16 \%$ in both lakes. The urban lakes are vulnerable to various environmental factors, which is responsible for the dynamic changes in physico-chemical and biological variables (Samal et al. 2004a). Presence of oligochaete species in Rabindra Sarovar belonging to the family Tubificidae (Bothrioneurum hortensis, Limnodrilus hoffmeisteri and Branchiura sowerbyi) indicates eutrophic status of the lakes (Mukherji and Nandi, 2004). Mukherji and Nandi (2004) reported that the fluctuation in estimated biomass of total benthos is related with the composition and benthic population density of the wetlands, which is in accordance with the present study. Dense littoral submerged macrophytic vegetation in Rabindra Sarovar made the lake a preferable habitat of macrobenthic fauna. The presence of pulmonate snails, oligochaetes and chironomid larvae in almost all sites of Rabindra Sarovar. All littoral region in Subhas Sarovar covering about $35 \%$ to $40 \%$ of the lake water area provided with Vallisneria growth. Presence of only Vallisneria sp. and absence of other submerged macrophytes indicating some factors favouring Vallisneria growth and extinction of other species which required details study regarding ecology and behaviour of the species. Enrichment of sedimented organic matters from ground water and surface run off may favoured the maximum benthic growth and reproduction during monsoon.

The cycling of oxygen levels in aquatic ecosystems is a natural process, and usually follows some seasonal pattern. Fish kills have been recorded during our observation period in the Subhas Sarobar. The influx of nutrient and sediment from allochthonous and autochthonous sources has contributed to a greater potential for fish kills. So it is very important to take an depth-integrated approach to describe the lake stratification, which creates a thermal/density barrier to oxygen transfer between the epilimnion and hypolimnion of a lake, thus inhibiting reoxygenation of hypolimnetic waters. The dissolved oxygen curve for both the lake give an indication of the inherent relationship between DO and temperature and is known as the clinograde curve, characteristic of eutrophic lakes, which shows decreasing DO levels with depth and is indicative of hypolimnetic DO depletion.

The long-term solution to this problem is to reduce the quantity of nutrients finding their way into waterbodies to a level that does not disturb their ecological balance. Methods used most often include air and water pumps, or mechanical agitation can be implemented to prevent or reduce the 
effects of a dissolved oxygen fish kill. The most effective means of reducing fish kills is to educate the fishermen and hunters. This can go a long way to minimize the nutrients and other chemical constituents of stormwater that contribute to low dissolved oxygen. Thus in order to keep a healthy condition for the growth of the higher aquatic life forms (i.e. fish) in Rabindra Sarobar and Subhas Sarobar, a regular Dissolved Oxygen monitoring is to be carried out. An understanding of the basic physical, chemical and biological processes involving oxygen dynamics and the response of the stratification to fish is required for manipulation of environment to favour greater production and the sustenance of ecosystem. However, lack of long-term time series limnological data further imparts the need of large scale hydrodynamics study both in measurement and modeling scale in these lakes.

\section{Acknowledgements}

The authors wish to thank the authorities of Kolkata (erstwhile Calcutta) Improvement trust (or KIT) for permitting and providing necessary facilities during fieldwork at the Rabindra Sarobar and Subhas Sarobar. We wish to express our gratitude to the DAAD, (Deutscher Akademischer Austausch Dienst) Bonn, Germany which financed (A/04/06852) the water quality modeling research carried out at the University of Konstanz, Germany as part of its developmental assistance during the tenure of the Fellowship. Financial support also came from the School of Water Resources Engineering, Jadavpur University in the form of study grant to the first author.

\section{References}

APHA, AWWA, WPCF 1989. Standard methods for the examination of water and waste water, $7^{\text {th }}$ Edn., Washington, D.C.

Barbanti, L.,W. Ambrosetti and A. Rolla. 1981. Dipendenza della temperature dell'acqua superficiale da temperature atmosferica e radiazione solare nei laghi italiani, Memoria Istituto Italitaliano di Idrobiologia., 39: 65-98.

Biswasroy, M., Roy, P.K., Mazumdar, A., Majumder, M. and Samal, N.R. 2012a. Water quality monitoring by multivariate statistical methods in the Alpine lake of Darjeeling Himalaya, India, International Journal of Advanced Scientific and Technical Research, 6: 115-131.

Biswasroy, M., Roy, P.K., Samal, N.R. and Mazumdar, A. 2012b. Socio-economic Valuations of Wetland Based Occupations of Lower Gangetic Basin through Participatory Approach, Environment and Natural Resources Research, Canadian Center of Science and Education, 2: 30-44. 
Biswasroy, M., Roy, P.K., Mazumdar, A., Majumder, M. and Samal, N.R. 2012c. Water quality monitoring by multivariate statistical methods in the Alpine lake of Darjeeling Himalaya, India, International Journal of Advanced Scientific and Technical Research, 6: 115-131.

Biswasroy, M., Samal, N. R., Roy, P. K., and Mazumdar, A. 2010. Human wetland dependency and socioeconomic evaluation of wetland functions through participatory approach in rural India. International Journal of Water Science and Engineering, China, 3: 467-479.

Biswasroy, M., Samal, N. R., Roy, P. K., and Mazumdar, A. 2011. Watershed management with special emphasis on fresh water wetland: a case study of Mathura beel in West Bengal, India, Journal of Global Network of Environmental Science and Technology, Athens, Greece, 13: 1-10.

Bonnet, M.P., Poulin, M. and Devaux, J. 2000. Numerical Modeling of thermal stratification in a lake reservoir: Methodolgy and case study, Journal of Aquatic Sciences., Basel, 62: 105-124.

Das Rajib, Samal, N. R., Roy, P. K. and Mitra D. 2006. Role of Electrical Conductivity as an Indicator of Pollution in Shallow Lakes. Asian Journal. of Water, Environment and Pollution, 3: 143-146.

Goudsmit G.-H., Burchard H., Peeters F. and West A. 2002. Application of k-e turbulence models to enclosed basins: the role of internal seiches Journal of Geophysical Research 107, C12: 1-13

Joehnk, K.D., Umlauf, L., 2001. Modelling the metalimentic oxygen minimum in a medium sized alpine lake. Ecological Modelling 136, 67-80.

Klug, J.L., Richardson, D.C., Ewing, H.A., Hargreaves, B.R., Samal, N.R., Vachon, D., Pierson, D.C., Lindsey, A.E., Donnell, D. O', Effler, S.W. and Weathers, K.C. 2012. Ecosystem effects of a tropical cyclone on a network of lakes in northeastern North America. Environmental Science and Technology: 46: 1169311701.

Livingstone, D. M. and Imboden, D.M. 1996. The prediction of hypolimnetic oxygen profiles: A plea for a deductive approach. Canadian Journal of Fisheries and Aquatic. Sciences, 53: 924-932.

Maclntyre, S., Jonsson, A., Jansson, M., Aberg, J., Turney, D.E. and Mailler, S.D. 2010. Buoyancy flux, turbulence, and the gas transfer coefficient in a stratified lake, Geophysical Research Letters, _37: L24604

Mazumdar, A., Samal, N.R., Roy, D., and Gangopadhyay, A. 2007. Physico-Chemical Characteristics of Water in a shallow lake Rabindra Sarobar in Metropolis Kolkata, Journal of Institute of Engineering. (IE$\mathrm{CH})$, India, 88: $32-40$. 
Mukherji, M. and Nandi, N.C., Studies on Macrozoobenthos of Rabindra Sarovar and Subhas Sarovar in Kolkata in Relation to Water and Sediment Characteristics, Rec. Zool. Surv. India Occ. Paper no. 225, 2004.

Peeters, F., Straile, D., Lorke, A. and Ollinger, D. 2007. Turbulent mixing and phytoplankton spring bloom development in a deep lake, Limnology and Oceanograhy, 52: 286-298.

Pierson, Donald C., Samal, N.R., Owens, E. M., Schneiderman, E. M. and Zion, M.S. 2013 Changes in the Timing of Snowmelt, and the Seasonality of Nutrient Loading: Can Models Simulate the Impacts on Freshwater Trophic Status? Hydrological Processes, 27: 3083-3093.

Samal, N.R., 2004. Study of morphometry and hydrothermal analysis of a tropical shallow Indian lake, report submitted to DAAD (A/04/06852), Bonn, Germany.

Samal, N. R., A. H. Matonse, R. Mukundan, M. S. Zion, D. C. Pierson, R. K. Gelda, and E. M. Schneiderman. 2013 Modelling potential effects of climate change on winter turbidity loading in the Ashokan Reservoir, NY, Hydrological Processes, 27, 3061-3074.

Samal, N.R., Jöhnk, K.D., Peeters, F., Bäuerle, E., Mazumdar, A., 2008. Mixing and internal waves in a small stratified Indian Lake: Subash Sarobar. In: Mohanty, P.K. (ed.) Monitoring and Modelling Lakes and Coastal Environments. Springer, Berlin, pp. 248.

Samal, N. R. \& Mazumdar, A. 2005a. Artificial boundary effect on primary productivity of the littoral garden. Journal ofEnvironmental Protection 25: 334-338.

Samal, N. R. \& Mazumdar, A. 2005b. Management of lake ecosystem. Journal of Ekologia 3: 123-130.

Samal, N. R., Mazumdar, A., Johnk, K. D. \& Peeters, F. 2009. Assessment of ecosystem health of tropical shallow waterbodies in eastern India using turbulence model. Journal of Aquatic Ecosystems Health Management Society 12: 215-225

Samal NR, Pierson DC, Huang Y, Read J, Anandhi A, Owens EM. 2012. Impact of climate change on Cannonsville reservoir thermal structure in the New York City Water Supply. Water Quality Research Journal, Canada 47: 389-405.

Samal, N. R., Roy, D., Mazumdar, A. \& Bose, B. 2004a. Seasonal response of water temperature of Rabindra Sarobar, the National Lake, in relation to $\mathrm{pH}$, dissolved oxygen, biochemical oxygen demand and chemical oxygen demand. Journal of Public Health Engineering 2, 39-42. 
Samal, N. R., Roy, D., Mazumdar, A. \& Bose, B. 2004b. Influence of thermal stratification on dissolved oxygen in Subhas Sarobar, Kolkata. Journal of Curriculum Sciences 7 (1), 259-266.

Samal, N. R., Roy, P. K., Biswas, M. \& Mazumdar, A. 2010. Summer thermal stratification: an indicator of water pollution in shallow lake Journal of Chemical Engineering, Institute of Engeering (India), 90, 37-43.

Samal, N.R., Saha, P., Biswas, M., Roy, P.K., Ramana, R. V. and Mazumdar, A. 2011. Limnological analysis of an urban polluted lake in Bangalore city in India, International J. desalination and water treatment, (www.deswater.com), USA, 30 (2011) 217-228.

Wetzel, R.G. (1983),: "The Oxygen Content in freshwater", Limnology, M. Brown. pp.172.

Yao, H., Samal, N.R., Joehnk, K.D., Fang, X., Bruce, L.C., Pierson, D.C., Rusak, J.A. and James, A. 2014. Comparing ice and temperature simulations by four dynamic lake models in Harp Lake: past performance and future predictions, Hydrol. Process. (2014), DOI: 10.1002/hyp.10180 